\title{
Elderly man with a pulmonary mass and osteolytic lesions: is it primary pulmonary plasmacytoma or multiple myeloma with an extramedullary pulmonary nodule?
}

\author{
Aung Myint Tun, ${ }^{1}$ Yu Yu Thar, ${ }^{1}$ Aye Min Soe, ${ }^{1}$ Ei Ei Naing ${ }^{2}$
}

${ }^{1}$ Department of Medicine, Division of Hematology and Oncology, The Brooklyn Hospital Center, Brooklyn, New York, USA

${ }^{2}$ St George's University School of Medicine, True Blue, Grenada

\section{Correspondence to} Dr Aung Myint Tun, atun345@gmail.com

Accepted 16 June 2016

\section{CrossMark}

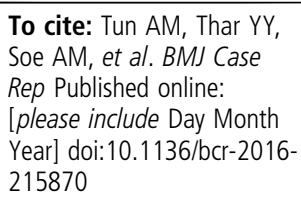

\section{DESCRIPTION}

A 69-year-old non-smoking African-American man was referred for management of hypercalcaemia with a corrected serum calcium level of 13.2 $\mathrm{mg} / \mathrm{dL}$. He reported worsening bone pain of lower lumbar vertebrae, right shoulder and left hip for 1 week, with associated weight loss. Physical examination disclosed mild spinal tenderness and a conjunctival pallor. Further investigations showed haemoglobin $8.4 \mathrm{~g} / \mathrm{dL}$; creatinine $2.5 \mathrm{mg} / \mathrm{dL}$; parathyroid hormone (PTH) $11.7 \mathrm{pg} / \mathrm{mL}$ (reference range: $8.7-77.1 \mathrm{pg} / \mathrm{mL}$ ) and anaemia of chronic disease on anaemia work up. Chest X-ray revealed right apical pleural thickening and an osteolytic lesion on the right second rib (figure 1). CT identified a mass lesion (figure 2) extending to adjacent vertebrae and ribs with multiple lytic bone lesions. Differential diagnosis included metastatic malignancy to bones and the right lung, primary lung cancer with osseous metastases and plasma cell dyscrasia. CT-guided biopsy (figure 3A) yielded numerous polymorphic plasma cell infiltrates, positive for CD138 (figure 3B).

\section{DISCUSSION}

Extramedullary pulmonary manifestations of multiple myeloma are uncommon findings that can be due to infection, an infiltrative process, a mass lesion or pleural effusion. ${ }^{1}$ Multiple myeloma

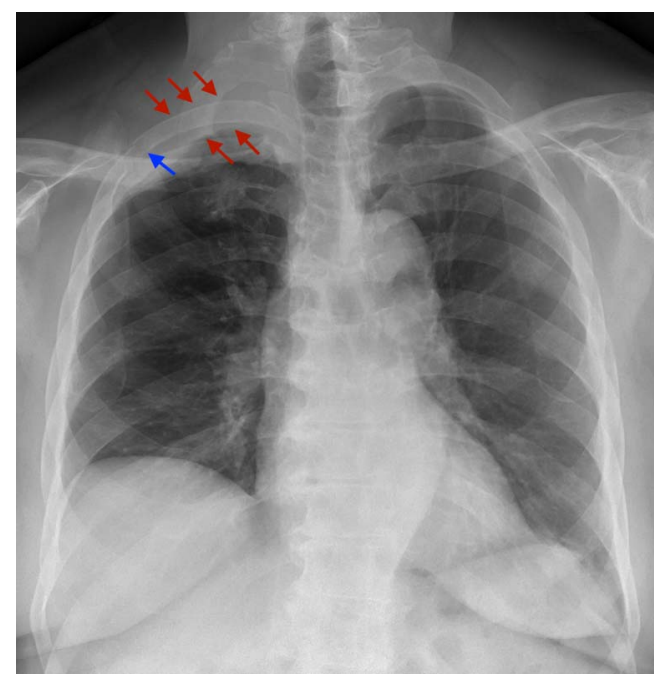

Figure 1 Chest X-ray showing right apical pleural thickening (red arrows) and osteolytic lesion of the right second rib (blue arrow). presenting as an extramedullary pulmonary nodule is a rare entity comprising about $1 \%$ of all cases. ${ }^{1}$ The diagnosis must be established by presence of clonal plasma cells on tissue biopsy.

The presence of these plasma cells could mean primary pulmonary plasmacytoma or multiple myeloma with extramedullary pulmonary dissemination. Therefore, all patients must be evaluated for multiple myeloma with (1) tests for classical CRAB symptoms: hypercalcaemia, renal impairment, anaemia or bone abnormalities; (2) bone marrow study for monoclonal plasma cells occupying $>10 \%$; and (3) presence of monoclonal protein in serum or urine or, in non-secretory multiple myeloma, $\geq 30 \%$ monoclonal plasma cells in bone marrow, is required. Symptomatic multiple myeloma with extramedullary pulmonary dissemination is diagnosed when the criteria mentioned above are fulfilled. ${ }^{2}$ The mainstay of treatment is systemic chemotherapy with/without autologous bone marrow transplantation, depending on patient's age, functional status and comorbidities. ${ }^{3}$ Unlike primary pulmonary plasmacytoma, the prognosis of pulmonary multiple myeloma is unfavourable due to its rapid progression. ${ }^{4}$

\section{MANAGEMENT OF THE PATIENT}

In our patient the hypercalcaemia with suppressed PTH was most likely secondary to multiple myeloma that responded well to intravenous

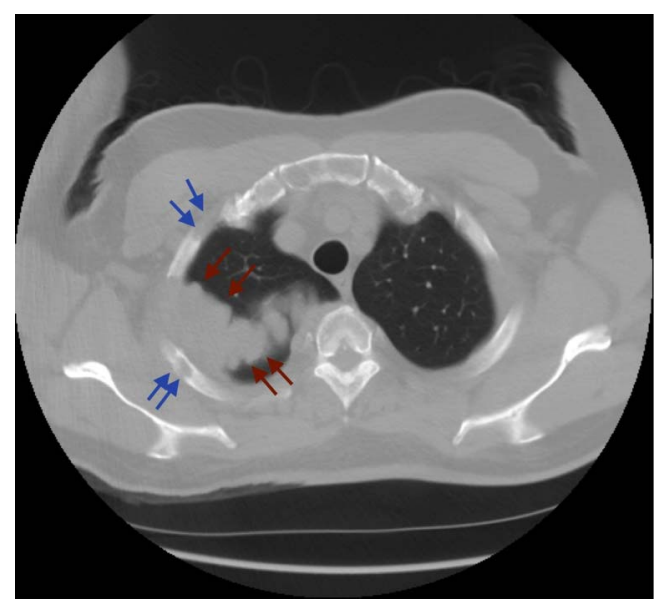

Figure 2 CT scan of the chest (axial view) revealing right apical lung mass (red arrows) and osteolytic lesions (blue arrows). 


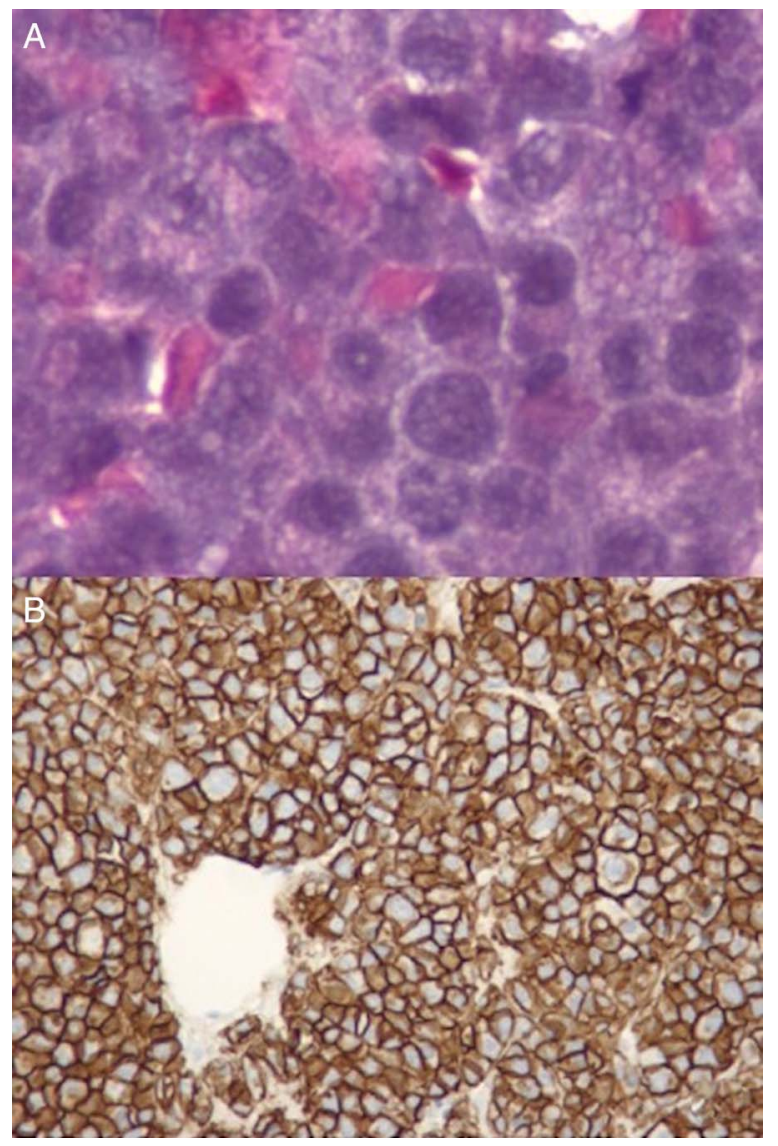

Figure 3 (A) CT-guided needle biopsy and microscopic examination of the lung mass reveal numerous polymorphic plasma cells (H\&E stain, $\times 600$ ) and (B) immunostain identifies cells with positive CD138 immunoreactivity.

hydration and pamidronic acid. There was neither serum immunoglobulin spike nor monoclonal protein on serum and urine protein electrophoresis. However, serum-free light chain assay revealed a $\kappa / \lambda$ light chain ratio of 3.82 (disrupted). Bone marrow examination yielded $70 \%$ clonal plasma cells. Pulmonary multiple myeloma was diagnosed and managed with chemotherapy, and the patient is currently being evaluated for autologous bone marrow transplantation.

\section{Learning points}

- Extramedullary pulmonary manifestations of multiple myeloma are uncommon.

- Differential diagnosis mainly consists of malignancy, especially lung or breast, with osteolytic metastases and multiple myeloma with extramedullary pulmonary involvement.

- It is prudent to exclude or proceed with work ups for multiple myeloma before the diagnosis of solitary plasmacytoma is made.

- Pulmonary multiple myeloma is an indicator of rapidly progressive disease.

Competing interests None declared.

Patient consent Obtained.

Provenance and peer review Not commissioned; externally peer reviewed.

\section{REFERENCES}

1 Kintzer JS Jr, Rosenow EC III, Kyle RA. Thoracic and pulmonary abnormalities in multiple myeloma: a review of 958 cases. Arch Intern Med 1978;138: 727-30.

2 Palumbo A, Sezer O, Kyle R, et al. International Myeloma Working Group guidelines for the management of multiple myeloma patients ineligible for standard high-dose chemotherapy with autologous stem cell transplantation. Leukemia 2009;23:1716-30.

3 Smith D, Yong K. Multiple myeloma. BMJ 2013;346:f3863.

4 Saidane 0 , Slouma $M$, Haouet $S$, et al. Cutaneous and pleural involvement in a patient with multiple myeloma. BMJ Case Rep 2015;2015:bcr2015211197.

Copyright 2016 BMJ Publishing Group. All rights reserved. For permission to reuse any of this content visit http://group.bmj.com/group/rights-licensing/permissions.

BMJ Case Report Fellows may re-use this article for personal use and teaching without any further permission.

Become a Fellow of BMJ Case Reports today and you can:

- Submit as many cases as you like

- Enjoy fast sympathetic peer review and rapid publication of accepted articles

- Access all the published articles

- Re-use any of the published material for personal use and teaching without further permission

For information on Institutional Fellowships contact consortiasales@bmjgroup.com

Visit casereports.bmj.com for more articles like this and to become a Fellow 